\title{
A project-based learning approach as a method of teaching entrepreneurship to a large group of undergraduate students in South Africa
}

\author{
Melodi Botha \\ University of Pretoria
}

\begin{abstract}
This paper discusses the development and execution of an entrepreneurship exhibition project held in South Africa, in which 1500 undergraduate first-year students took part. The current teaching practices in the course, resulting from project-based learning practices, have been developed out of an extensive review of entrepreneurship education literature and frameworks. The results of the assessment, conducted to measure student satisfaction with and opinions of the course, are included along with a summary of the experience gained while taking part in the project. In addition to the assessment, the results of the students' perceptions of entrepreneurial skills gained after the project are presented. Factor analysis took place and several statistical tests were performed to provide significant findings. This paper aims to share implementation - and assessment - of such a project as an opportunity for entrepreneurship educators to learn from others' experiences, and to contribute to the entrepreneurship education literature.
\end{abstract}

Key words: entrepreneurship education and training, project-based learning, entrepreneurial skills and experience gained

\section{Introduction}

There is a growing interest in entrepreneurship and education, and a number of studies have focused on what is being taught in entrepreneurship education in tertiary institutions (Fiet 2000; Gibb 1997; Henry, Hill and Leitch 2005; Kuratko 2005; and Timmons 2003). Co and Mitchell (2006:349) and Dhliwayo (2008:330) specifically focused their studies on South African universities, since in South Africa there have not been many studies to investigate the state of entrepreneurship education in the country. These studies have led to the question: "Are we equipping our entrepreneurship students with adequate skills to become entrepreneurs?" O'Neill (2004:5) agrees and adds the question: "What does an entrepreneurship student become if he or she does not become an entrepreneur?" Many definitions of entrepreneurship and an entrepreneur exist. For the purpose of this paper the following definition of an entrepreneur will be used: "It is a person who sees an opportunity in the market, gathers resources and starts and grows a business venture to satisfy these needs. He or she takes the risk of the venture and is rewarded with profit if it succeeds" (Nieman, Hough \& Nieuwenhuizen 2003:9).

There is a growing need for entrepreneurship education and training programmes in South Africa. Despite such widespread acknowledgement of supply and demand, there is a disparity in the content and quality of entrepreneurship education programmes on offer, including curriculum design, delivery methods and forms of assessment (Matlay 2006:705). Dhliwayo (2008:330) states that the 'new' entrepreneurship teaching style in South Africa should be action oriented to encourage experiential

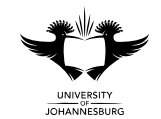


learning, problem solving and creativity and provide the best mix of enterprising skills and behaviours needed to create and manage a business. Entrepreneurship is an ongoing process that requires a myriad of talents, skills and knowledge, leading to unique pedagogies capable of stimulating and imparting knowledge simultaneously.

When looking at the international situation, Solomon (2007:168) emphasises the point that the challenge to educators will be to craft courses, programmes and major fields of study that meet the rigours of academia while keeping a reality-based focus and entrepreneurial climate in the learning experience environment. An analysis of a number of studies on entrepreneurship courses offered in business schools across the world has established that most of them use a combination of theoretical and conceptual approaches, often reinforced by detailed analysis of "practical" or "real-life" solutions, including case and field studies (Timmons 2003:5).

Entrepreneurship is normally taught in universities, in South Africa as well as internationally, by working with small groups of students because the subject contains many practical elements and there is a strong emphasis on "learning by doing". Gibb (1997:19) argues that entrepreneurial learning should entail learning by coping, learning from feedback from customers, learning by doing and learning by experimenting. Fayolle, Gailly and Lassas-Clerc (2006:710) agree that entrepreneurial teaching approaches and methods may involve "learning by doing", immersion in real-life situations, case studies and guest lectures by entrepreneurs. Furthermore, they maintain that the efficiency of the more didactic and conventional procedures such as classroom lectures must be assessed. Many researchers argue that entrepreneurial teaching should be unconventional, not tying the student to the four walls of the classroom, and should consist of learning by doing (Antoncic, Scarlat \& Erzetic 2004:199; Gibb 1997:19). These outside classroom activities include internships with start-up entrepreneurs, running personally owned small businesses on campus and several other practical group activities.

The challenge, however, is to use these methods to teach entrepreneurship to more than 1500 firstyear undergraduate students. This paper will introduce a teaching method aimed at using an outside classroom practical project and ways of assessing it. Furthermore, the paper will provide results of the students' perceptions of entrepreneurial skills gained as a result of the project. Therefore the purpose of the paper is threefold: firstly to introduce the project as a practical teaching method, secondly to explain the assessment of a large group of students, and thirdly to present empirical results indicating that the students gained entrepreneurial knowledge and skills as well as other critical thinking skills and teamwork stemming from the project.

The structure of the paper is as follows: a theoretical framework for entrepreneurship education is presented, followed by the literature review on entrepreneurship education at South African universities. Thereafter, theoretical components and a framework for project-based learning are provided, followed by the application of the first-year entrepreneurship exhibition project. The research methodology is explained from which research objectives and hypotheses are presented. The final section of this paper refers to the findings, the validity and reliability of the measuring instrument as well as several statistical tests. The paper ends with the discussion of the findings and a conclusion.

\section{Theoretical framework for teaching entrepreneurship}

According to Fayolle and Gailly (2008:571), and supported by Fiet (2000), the concept 'teaching framework/model' is rarely used in the entrepreneurship field, where there is no common framework or agreed good practices regarding how to teach or educate. Hannon (2006:302) states that it is important to recognise the complexity and diversity of the field and as such no single philosophy, conception or model of entrepreneurship education is likely to meet the broad scope of the field. Bechard and Gregoire (2005:107) define a teaching model as the representation of a certain type of setting designed to deal 
with a pedagogical situation in function of particular goals and objectives which integrates a theoretical framework justifying the design and in an exemplary character.

Fayolle and Gailly (2008:571) developed a coherent teaching framework including ontological and educational levels and aimed at providing educators and teachers with theoretical and practical guidelines. This model was used as the foundation for entrepreneurship teaching in this paper and is illustrated in Figure 1. On the ontological level, the authors propose an explicit definition and acknowledgement of what entrepreneurship is (and is not) as a teaching field and on the other hand a definition of what education implies for educators and for students within the entrepreneurship context. These concepts are defined in the next section of this paper.

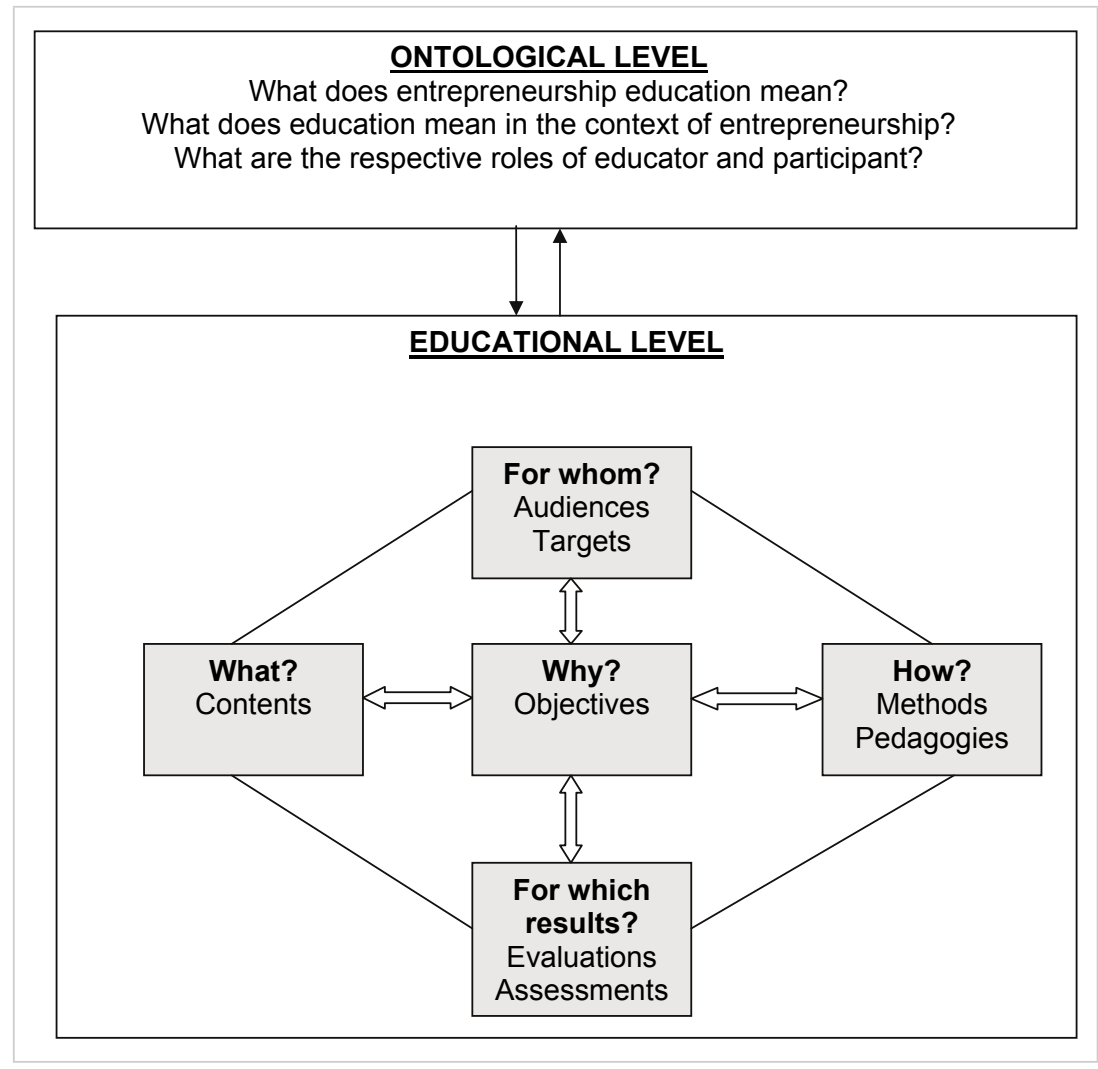

Figure 1: Teaching model framework for entrepreneurship education

The educational level relates to the design and the architecture of an education programme around five specific interrelated questions, which should be addressed in the following order:

1. Why (objectives, goals)?

Entrepreneurship courses should target clear and comprehensive objectives at the micro (individual, participant) level and at the macro (organisational, society) level. Aligning philosophy or purpose with learner expectations, needs and intended outcomes is likely to enhance the learner experience and educator effectiveness (Hannon 2006:302). 
2. For whom (targets, audiences)?

Entrepreneurship courses should be designed through a thorough understanding of the profile and background of the audience, particularly in terms of prior entrepreneurial exposure. There are significant differences between courses intended for example for graduate management students, $\mathrm{PhD}$ students and first year BCom students (the target group in this paper).

3. For which results (evaluations, assessments)?

Entrepreneurship courses should be evaluated or assessed by using a selection of evaluation criteria as well as an effective measurement thereof.

4. What (contents, theories)?

Hills (1988:116) conducted a study on the entrepreneurship programmes of 16 prestigious universities in the United States of America (USA) and found that each reflected a different model for teaching entrepreneurship. However, there were conceptual bases which included the business plan, the business life cycle and business functions. Fayolle and Gailly (2008:578) emphasise that the professional dimension of entrepreneurship education relates more specifically to practical knowledge, or know-how, and to a lesser extent to theoretical knowledge. This dimension relies on three kinds of knowledge: Know-what (what to do in order to start a business, or evaluate an opportunity); know-how (how to identify risks and prepare a business plan); and know-who (useful networks in a given context).

5. How (methods, pedagogies)?

The teaching method used in an entrepreneurship programme relates to the 'how' question of the framework. Examples of this include practical projects, the use of case studies, role-play and preparing business plans. In this paper, a project-based learning approach is identified as a teaching method to teach entrepreneurship to a large group of undergraduate students in South Africa.

This theory-driven approach to entrepreneurship education and the resulting teaching model highlighted have important theoretical and practical implications (Fayolle \& Gailly 2008:586). The theoretical implication is that there are a range of theoretical choices, objectives, pedagogical methods, teaching methods and learning processes which can be structured around a general framework, as outlined above. The practical implication is that an explicit conceptual framework should help the effective and systematic design, management and evaluation of new or existing programmes, along all the relevant dimensions.

The next sections deal with the literature review aiming to shed light on the application of the abovementioned concepts and questions raised in this framework.

\section{Entrepreneurship education at South African universities}

It is no longer a question of whether entrepreneurship can be taught at university level, but rather of developing and promoting the elements that can be taught (Henry et al. 2005:102; Kuratko 2005:580). Heinonen (2007:312) maintains that universities seem to have succeeded relatively well at teaching the 'sciences' of entrepreneurship by providing a conceptual background and stimulating the necessary analytical thought processes. What is needed is a shift from teaching to learning in an environment as close to real life as possible. Concrete experience gained through the active participation of students should be part of the curriculum (Heinonen and Poikkijoki 2006:83). Solomon (2007:172) agrees and identifies the 'new school' of teaching entrepreneurship. He suggests that it relies on some level of personal experience in technology or industry. Also, McMullan and Long (1987:264) state that effective entrepreneurial education requires students to have substantial hands-on experience working with 
community ventures so that they can learn to add value to real ventures and thus be prepared to add value to their own ventures.

Co and Mitchell (2006:349) argue that, as a result of the increased demand for entrepreneurship courses, it is important to understand how higher education institutions (HEIs) are meeting this increased demand and staffing the courses and programmes. In his study, Dhliwayo (2008:332) suggests that a prospective model is needed for South African tertiary institutions. The model focuses on linkages between the student, the university, government agencies, private sector, communities, entrepreneurs and small to medium sized businesses. In addition, the emphasis of the model is on experiential learning, in which students must learn from an environment as close to real life as possible. Yet the nation-wide study done by Co and Mitchell (2006:354) indicated that South African HEIs still predominantly adhere to traditional in-class methods of teaching although there is an emerging trend towards the utilisation of more modern techniques such as role play and computer simulations. Their study pointed out that at undergraduate level the most commonly used in-class method is the traditional class lecture (65 per cent), followed by the creation of business plans ( 58 per cent), discussions ( 55 per cent), case studies (52 per cent) and guest speakers (45 per cent). Botha (2006:57) indicates that South African entrepreneurship education and training programmes pay intensive attention to transferring knowledge but are weak on the skills and attitudinal aspects that are crucial for any potential and start-up entrepreneur. Pretorius, Van Vuuren and Nieman (2005:424) agree that the transfer of necessary knowledge and skills is usually the easiest part of any course and, in this approach; it is taken as a prerequisite for changing behaviour. Dhliwayo (2008:331) is of the opinion that lecturing as a method of teaching entrepreneurship in South African universities needs to be changed, because the approach often reveals more about the teacher than about the subject being taught.

In comparison with the above, Solomon (2007:168) did a study on examining entrepreneurship education in the USA and found that entrepreneurship educators are increasingly using guest speakers and class discussions in preference to the traditional approach of class lectures. In order to develop potential entrepreneurs, South African tertiary institutions should focus more on unconventional teaching methods such as practical projects to teach entrepreneurship.

\section{Defining entrepreneurship education}

Hynes (1996:10) distinguishes between entrepreneurship training and entrepreneurship education. Entrepreneurship training aims to develop knowledge or skills that enable an individual to achieve an effective performance. Entrepreneurship education aims to enable an individual to assimilate and develop knowledge, skills and values that allow a broader range of problems to be addressed. Based on this literature review, the focus in South Africa is currently more on providing entrepreneurial training and less on entrepreneurial education.

Jamieson (1984:9) and Laukkannen (2000:26) have suggested a two-category framework by which to organise entrepreneurship education. They distinguish between:

- Education about entrepreneurship. This involves developing, constructing and studying the theories referring to entrepreneurs, firm creation, contribution to economic development, entrepreneurial process and small and medium-sized firms. It takes into account undergraduate, master's and PhD students as well as policy makers and researchers. It views entrepreneurship as a social phenomenon.

- Education for entrepreneurship. This addresses present and potential entrepreneurs with the objective of developing and stimulating the entrepreneurial process, providing all the tools necessary for the start-up of the new venture both inside and outside an existing organisation. 
Klandt (1993:41) indicates that educating for entrepreneurship involves using techniques such as the following: videos, practical work, writing business plans, computer simulations, role-playing games, working with entrepreneurs and joining a students' entrepreneurial club. Co and Mitchell (2006:357) believe that at present the techniques being used in South Africa educate about entrepreneurship rather than for it. There should be an increased use of more interactive methods such as role-playing and simulation for students to practise analytical and decision-making skills. Outside classroom methods such as practical group work can be used to teach students problem solving as well as teamwork. These components are useful when students are exposed to real-life entrepreneurial projects.

The educational setting appears to be fertile ground for the development of perceived self-efficacy: participation in student associations, evaluation of work in and out of class and peer evaluation (Fayolle et al. 2006:709; Laukkannen 2000:37). All these elements can contribute to knowing how one sees oneself, whether one believes one is able to become a successful entrepreneur and handle problems, ambiguity and pressure. It is also referred to as problem-based learning, which is characterised as being a studentcentred approach in which teachers are facilitators rather than disseminators and open-ended problems serve as the initial stimulus and framework for learning (Bell 2008:54). It is therefore important to encourage student-led activities inside and outside the classroom in order to foster involvement in the learning process, while still highlighting the importance of the underlying theoretical concepts. This view is supported by Fiet (2000) and Kuratko (2005), and Heinonen (2007:313) adds that university-level courses face the challenges of supporting students towards learning the theoretical concepts and putting them into practice. Rae's (1999:184) view provides a summary; for an entrepreneurship programme to be successful in teaching entrepreneurship, three sources or forms of entrepreneurial learning are needed: active (practical learning); formal (theoretical learning) and social (learning from others). This paper has adopted Rae's view by incorporating all the sources of entrepreneurial learning into the course and specifically applying the active and social forms throughout the project.

\section{$4 \quad$ Project-based learning as a teaching method}

According to Thompson and Beak (2007:278) research on project-based learning in the university business classroom is scant, indicating that much greater opportunity exists for its incorporation in this realm. Project-based learning is a comprehensive approach to classroom teaching and learning that is designed to engage students in investigation of authentic problems (Blumenfeld, Soloway, Marx, Krajcik, Guzdial and Palincsar 1991:369). Scarbrough, Bresnen, Edelman, Laurent, Newell and Swan (2004:492) add that project-based learning is seen as encompassing the generation, capture and transfer of learning by individuals and groups within project settings. Blumenfeld et al. (1991:369) used a project-based learning approach in a study conducted on how students can get motivated to really understand the material, not just pass the tests. These students developed and pursued solutions to non-trivial problems by asking and refining questions, debating ideas, designing plans and/or experiments, communicating their ideas and findings to others and creating artefacts. These authors identified several components necessary for project-based learning to be effective (Figure 2). 


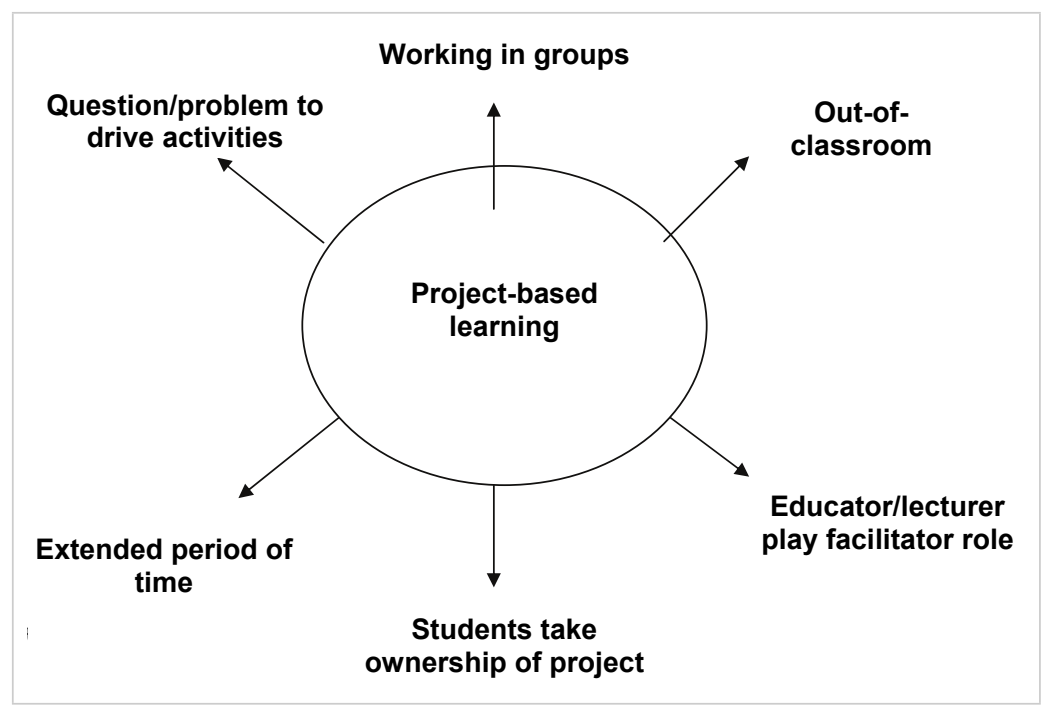

Figure 2: Essential components of project-based learning

As demonstrated in Figure 2, project-based learning places students in realistic, contextualised problemsolving environments so that the students work in teams/groups to solve problems, preferably outside the classroom and over an extended period of time. Thompson and Beak (2007:280), supported by Frank, Lavy and Elata (2003:280), state that the projects are primarily student-directed, which means that the instructors need to function more as facilitators and coaches, whereas the students must move out of the 'passive learner' role.

Law and Chuah (2004:181) developed a framework on project-based action learning as a learning approach in learning organisations. This theoretical framework was adapted to fit the university environment and used as the basis of this paper. 


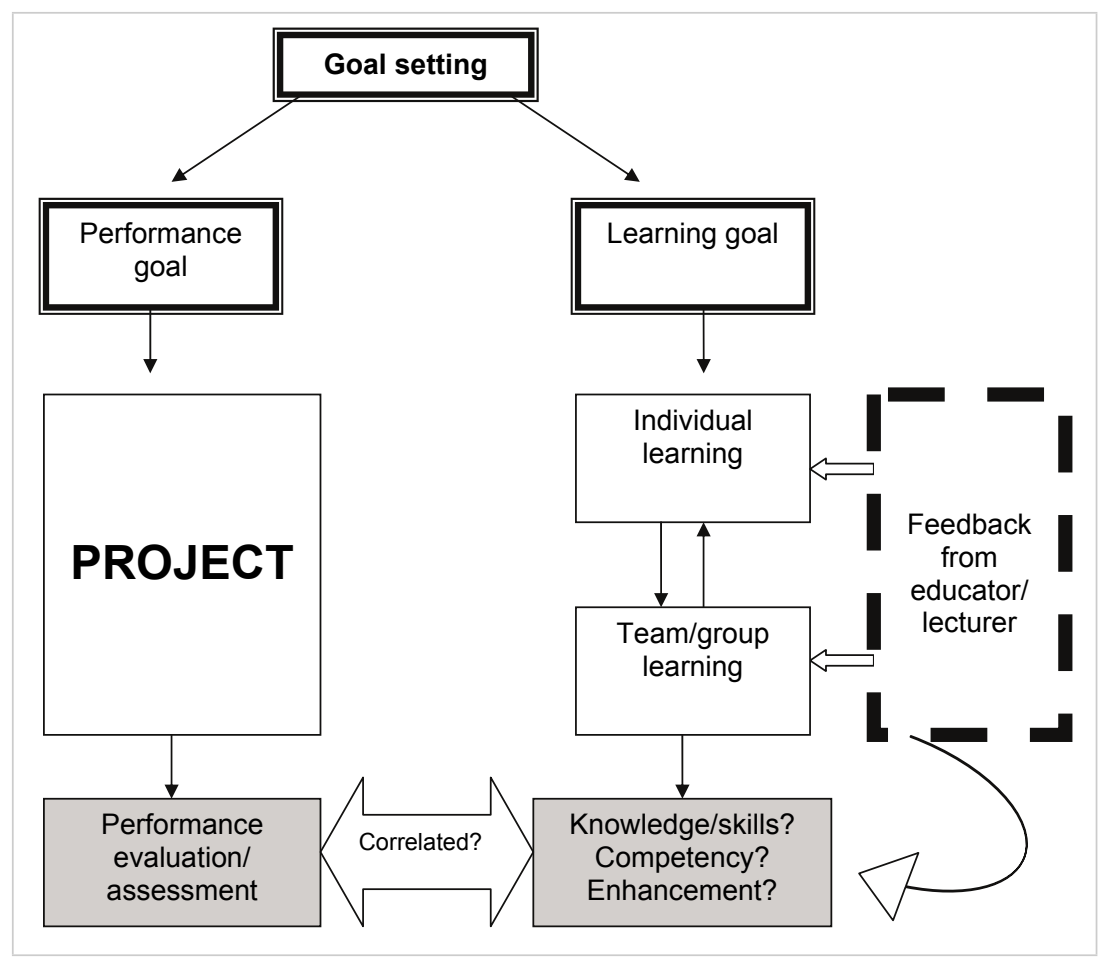

Figure 3: Framework for project-based learning

Figure 3 illustrates that there are several activities taking place within the framework. Law and Chuah (2004:181) emphasise the various dimensions in this learning framework:

- $\quad$ The project and learning goals are the starting blocks of this learning framework.

- The development of learning approaches and motivation systems enhances individual and team learning. Scarbrough et al. (2004:493) identify two views of project-based learning: learningby-absorption (by means of absorbing new information, assimilating it and then applying it to commercial ends) and learning-by-reflection (the individual possesses knowledge of the circumstances of their actions and the interpretive and normative rules that they follow).

- An evaluation system is developed for both self and objective evaluation/assessment.

- The facilitation and evaluation process is designed to affect individual as well as team learning.

- The educator/lecturer plays an active role in the evaluation/assessment process whereby feedback is given to the groups.

- There should be a correlation between the knowledge and skills gained and the performance achieved by the teams/groups.

\section{Framework application: The Business Management}

\section{(Ondernemingsbestuur, OBS 124) entrepreneurship exhibition project}

If it is true that we remember 90 per cent of what we do, then a course cannot be taught without students being actively involved in the doing and learning themselves. As the literature review points out, this is undoubtedly true of a subject such as entrepreneurship. One would normally approach the 'I talk, you 
listen, you learn' teaching style with 1500 first-year students but, instead, it was decided to approach the 'You do, we listen, you remember' teaching style. The first-year entrepreneurship exhibition project was initiated to encourage students to participate actively in the semester course and to develop critical thinking skills. This subject is referred to by its subject code, namely OBS 124 .

Until 2007, only students who were enrolled for BCom Entrepreneurship were exposed to entrepreneurship, with the exception of one third-year choice subject for students from other faculties at the University of Pretoria. However, the various groups never exceeded 300 students. In 2006 it was decided that all BCom first-year students should be exposed to entrepreneurship in the second semester of their first year. Therefore almost 1800 students enrolled for OBS 124 in 2007, and in 2008 the number has grown to almost 2500 students.

While this was an enormous opportunity, it was also a huge challenge, since entrepreneurship is seen as one of the subjects that cannot be taught without a practical leg as part of the curriculum. Some of the well-known researchers in the field of entrepreneurship teaching and education noted that entrepreneurship can only be learnt by practically demonstrating what has been learnt (Drucker 1985; Gartner and Vesper 1994; Katz 2003; Kuratko and Hodgetts 2004; Timmons and Spinelli 2005), to name but a few. Morris, Kuratko and Schindehutte (2001) add that students have to learn the theory, principles and concepts of entrepreneurship while also developing an appreciation for pragmatic considerations by applying themselves to projects rooted in real-world practice.

There are various ways of teaching entrepreneurship practically and engaging students to become more involved in the learning. Here are only a few teaching methods used to teach entrepreneurship:

- $\quad$ Case studies

- $\quad$ Preparing business plans

- Group projects/assignments

- Entrepreneurial apprenticeships (internship)

- Games and simulations

- Internet-based learning

- Role play

- $\quad$ Experiential examinations

The challenge, however, lay in the fact that only ten lecturers were available to evaluate and assess the practical component of OBS 124. So, how does one incorporate a practical project into a group of students this size and how will it be assessed?

The first-year entrepreneurship project consisted of an exhibition day where the first-year entrepreneurship students were divided into groups of four to five students. According to Bell (2008:54), group work is essential to project-based learning for several reasons. First, group work helps develop learning communities in which students feel comfortable developing new ideas and raising questions about the material. In addition, group work enhances communication skills and students' ability to manage group dynamics. These are skills much needed by those who are becoming real-life entrepreneurs. Finally, group work can enhance student achievement because it means that students become actively involved in the work and are held accountable for their actions by group members.

The purpose of this project was to engage students in giving an account of their view of entrepreneurship after having received the adequate theoretical knowledge to do so (goal setting). Students had to come up with creative and innovative ways of demonstrating, by practical application, what they had learnt in entrepreneurship (OBS 124). Furthermore, they had to incorporate all the topics and chapters covered during the semester (learning goal). These topics/study themes included characteristics of entrepreneurs, business start-up, business plans, resources available to entrepreneurs, business forms, 
family businesses, franchising and business buy-outs, to name but a few. The project was communicated to students from the beginning of the semester by using their study guide and the university click-up system. ${ }^{1}$ After the completion of each study theme, lecturers spent time on the project and assisted students with what they needed to do on the exhibition day.

Here are some examples of what the students presented on the day:

- Reality television shows, such as 'Survivor' and 'Who Wants to be an Entrepreneur'? game shows

- Fashion shows

- Several play performances

- Several board games, which the students developed and played

- Exhibitions to portray entrepreneurship (Note that no buy-and-sell or flea market stalls were allowed.)

- $\quad$ Detailed posters illustrating concepts/topics

- Dress-up characters by students illustrating entrepreneurship

- Films/videos illustrating entrepreneurship

- Cookery shows and classes

The outcome of the project was not only for students to pass the semester, but also to engage in active learning while presenting their exhibitions. Many students also involved the lecturers in their exhibitions by asking them to participate in their individual game show, board game, fashion show and so on. Overall it was an enjoyable, informative and creative day for both students and lecturers.

\section{Impact on learning}

As mentioned previously, students learnt by exhibiting their views of entrepreneurship. Roles were actually switched, and students demonstrated to the lecturers what entrepreneurship is all about. The project proved that student engagement in learning could be done successfully with any number of students. Furthermore, the student learning environment was shown to be improved and students could develop their critical thinking skills and think 'out of the box'. Student feedback was collected after the project, the results of which are presented later in the paper.

\section{Assessment technique}

No written assignment was done because a paperless innovative project was introduced. On the exhibition day the lecturers used a comprehensive evaluation sheet and walked around to observe as students exhibited entrepreneurship in their own way. Lecturers then assessed each group as the members portrayed their projects.

The advantages of using this assessment method, for both lecturers and students, are:

- No written assignment needed to be marked.

- $\quad$ Time is saved for lecturers and students.

- $\quad$ All group members had to participate in the project - whereas with a written assignment there are always students who do not contribute.

- Students had to take an active part in the project while learning at the same time.

- Students learnt other valuable skills such as time management and team work.

- Group members learnt from one another.

- $\quad$ Groups learnt from other groups (350 groups participated in the project). 


\section{Limitations of this type of assessment}

One potential limitation of the assessment is that there is no baseline data with which to compare the survey results. Ideally, a comparison group consisting of a similar sample of students should also be asked to complete the survey to see whether the project was really having an impact on the students (Okudan and Rzasa 2006:207). In this case a comparison (control) group could not be obtained, because of the large number of students as well as the fact that it was the first time that such a project was introduced. The next solution would be to administer both pre-survey and post-survey tests to analyse changes over time. Unfortunately, the assessment of the course started late in the semester, thus missing the opportunity to capitalise on early data collection. Presented assessment data will serve as the baseline comparison data for future revisions of the course.

\section{Research methodology}

A literature review and empirical research are presented. Quantitative research was conducted, using a selfdeveloped research questionnaire as the measuring instrument. In 2007, 1800 students were enrolled for the course, Entrepreneurship (OBS 124), and 1500 participated in the project. The questionnaires were distributed during the final week of lectures in November 2007. Probability sampling is done when there is a probability that any member of the population will be included in the sample, while non-probability sampling indicates that specific respondents who fit the sampling frame identified are included in the sample (Leedy 2004:18). In this study, non-probability sampling was used. A realised sample size of 460 was obtained from a target sample size of 900 . This represents a 51 per cent response rate. The response rate would have been higher if the questionnaire had been distributed directly after the project, but the researcher wanted to allow some time to pass during the project and its evaluation to enable students to have some time to reflect on their opinions. Nominal data, in this case demographic variables such as respondent gender, age, degree involved (major subject), home language and race were investigated using direct questions. Many open-ended questions were asked concerning students' perceptions of and opinions about the project. A three-point Likert-type scale was used to measure what students learned from the project and to measure whether entrepreneurial skills were gained. Factor analysis was done to confirm the validity and reliability of this measuring instrument. Descriptive statistics arising from opinions and expressions are presented and statistical tests provide inferential statistics.

\section{Primary and secondary objectives}

\section{Primary objective}

The primary objective was to determine whether a large group of undergraduate entrepreneurship students think that they gained entrepreneurial skills by means of the project-based learning approach.

\section{Secondary objectives}

The secondary objectives were:

- to determine whether the students who indicated that they enjoyed the project learnt more than the students who did not enjoy the project;

- $\quad$ to determine students' overall impressions of the project; and

- to determine what other skills students gained from the project, besides the course content skills. 


\section{Hypothesis and proposition statements}

Hypotheses as well as propositions are stated in this paper, because of the notion that a hypothesis statement is an empirically testable proposition (Cooper and Schindler 2001: 136).

The following hypotheses are tested:

H1: $\quad$ A large group of entrepreneurship undergraduate students had the perception that they did not gain entrepreneurial skills due to the project-based learning approach.

H1: $\quad$ A large group of entrepreneurship undergraduate students had the perception that they gained entrepreneurial skills due to the project-based learning approach.

H2: $\quad$ The students who enjoyed the project did not learn more than the students who did not enjoy the project.

H2: $\quad$ The students who enjoyed the project learnt more than the students who did not enjoy the project.

The following propositions are stated:

$\mathbf{P}_{\mathbf{1}}$ : $\quad$ The students' overall impression of the project is negative.

$\mathbf{P}_{2}$ : $\quad$ Students did not gain skills other than the course content skills from participating in the project.

\section{Findings}

A research questionnaire was given to the students after the end of the semester to evaluate the OBS 124 entrepreneurship exhibition project. The demographics of the sample are presented, and thereafter descriptive statistics about the project are provided. The validity and reliability of the research questionnaire are illustrated and the final section presents statistical tests highlighting statistically significant differences.

\section{Demographic information}

The following demographic information: gender, age and degree of study, was gathered and is summarised in Table 1.

Table 1: Composition of the sample

\begin{tabular}{|c|c|c|c|c|c|}
\hline Gender & Frequency (n) & Age & Frequency (n) & Degree of study & Frequency $(n)$ \\
\hline Male & 178 & $16-20$ & 401 & BCom General & 84 \\
\hline \multirow[t]{4}{*}{ Female } & 279 & $21-26$ & 49 & BCom Other & 245 \\
\hline & & 30 and older & 2 & BCom entrepreneurship & 6 \\
\hline & & & & $\mathrm{BSc}$ & 98 \\
\hline & & & & Other & 21 \\
\hline Total & 457 & & 452 & & 454 \\
\hline
\end{tabular}

Students from all the University of Pretoria campuses took part in the project. The main campus was represented by 70 per cent of the respondents, 10 per cent studied on the Groenkloof campus, 18 per 
cent on the Mamelodi campus and 2 per cent on the Ndebele campus. Most of the respondents studied BCom Own Choice and only six of the respondents studied BCom Entrepreneurship. The BCom Other as identified in Table 1 includes BCom Internal Auditing, Economics, Communication, Law, Marketing, Tourism, Human Resources, Financial Management, Investment Management, Business Management, Statistics, Recreation and Sport Management and Consumer Sciences. The gender of the sample consisted of 61 per cent female and 39 per cent male students. The youngest respondent was 16 years of age and the oldest respondent 33 years. The majority of respondents would be expected to fall into the 16 -to-20 age category, since this was a first-year project and course.

\section{Descriptive statistics}

\section{OBS 124 entrepreneurship exhibition project feedback}

When asked whether the students enjoyed the project, 70 per cent of the respondents indicated that yes, they did enjoy participating in the project, whereas 30 per cent indicated that no, they did not. The students were asked whether they struggled to understand the project and 69 per cent of the respondents indicated that they did not struggle to understand the project. Ninety percent of the respondents rated their overall impression of the project as average/positive. Only 10 per cent indicated that their overall impression of the project was negative.

\section{Contribution of the project}

In response to an open question, the respondents indicated that the project contributed towards the improvement of the quality of their skills in the following ways:

- They became creative and innovative and developed critical thinking skills (135 respondents, 29 per cent).

- $\quad$ They acquired presentation and communication skills (48 respondents, 10 per cent).

- They began to grasp entrepreneurial application - how to start a personally owned business (81 respondents, 18 per cent).

- They discovered how to work in a group (74 respondents, 16 per cent).

- $\quad$ The project assisted them to prepare for the examination (15 respondents, 3 per cent).

Next, the respondents were asked to summarise what their greatest gains were from the project and the most significant answers were:

- $\quad$ Teamwork

- Knowledge of entrepreneurial skills

- Creativity and innovation

- Preparation for tests and the examination

One key success factor of the project is that students have been told about it at the beginning of the semester and were continuously reminded about it throughout the semester. After the completion of each study theme, there was a practical period during which lecturers assisted students with the project.

\section{Improvements to the project}

Students were asked to make recommendations regarding ways in which the project could be improved in the future, and the following suggestions were made: 
- $\quad$ The project should count more towards the semester mark.

- The groups should consist of more members.

- $\quad$ The project should be expanded to the business world.

- $\quad$ To save time, more lecturers are needed to evaluate.

- A prize should be given to the best group.

\section{Validity and reliability of the research questionnaire}

Factor analysis was carried out to confirm the validity and reliability of the research questionnaire used. Three factors were generated and are presented in Table 2 . In this paper, 0.600 was used as the benchmark against which to measure the Cronbach alpha values. From the 17 items posed on a 3-point Likert scale, the derived three factors delivered excellent Cronbach alpha results as can be seen in Table 2. A value of 0.8907 was obtained for all the variables used. The three factors that were generated were named: Creativity and innovation (Factor 1), Entrepreneurial characteristics and orientation (Factor 2), Routes to entrepreneurship (Factor 2). These three factors are labelled as the course content factors as they measured the first-year entrepreneurship content (OBS 124). It is interesting to note that the creativity and innovation variables came out as one factor and the rest of the entrepreneurial characteristics as Factor 2. This emphasises the importance of creativity and innovation as part of this project and its importance to a real-life entrepreneur.

Table 2: Factor analysis

\begin{tabular}{|c|c|c|c|}
\hline \multirow{4}{*}{ 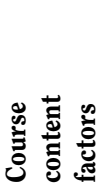 } & Factors generated & Eigen values & Cronbach alpha \\
\hline & Creativity and innovation & 6.36974 & 0.6185 \\
\hline & Entrepreneurial characteristics and orientation & 1.42194 & 0.8427 \\
\hline & Routes to entrepreneurship & 1.28940 & 0.8583 \\
\hline
\end{tabular}

In total the factors explained 45 per cent of the variance. The correlation between Factors 1 and 2 was relatively high, 0.657 , but is acceptable since the variables are not independent of one another.

\section{Testing the statistically significant differences}

The respondents were asked to specifically indicate how the project contributed to the enhancement of skills. The chi-square test was used before and after the project to measure the respondents on entrepreneurial skills and course content. The chi-square test was carried out on all the individual variables because the researcher wanted to measure each and every skill. Course content consisted of the most important areas of knowledge that students had to know after they completed OBS 124. Table 3 below illustrates which variables formed part of each of the factors that were generated from the factor analysis. 
Table 3: Chi-square test: comparison between the before and after measurement of the respondents' course content skills gained

\begin{tabular}{|c|c|c|c|c|}
\hline \multirow{3}{*}{ 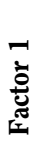 } & Variable & Frequency $(n)$ & Chi-square value & P-value \\
\hline & Being creative & 425 & 84.6859 & $<0.0001^{* * *}$ \\
\hline & Being innovative & 425 & 85.0623 & $<0.0001^{* * *}$ \\
\hline \multirow{5}{*}{ 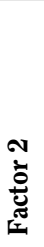 } & Defining entrepreneurship & 422 & 28.8257 & $<0.0001^{* * *}$ \\
\hline & The entrepreneurial process & 424 & 46.0617 & $<0.0001^{* * *}$ \\
\hline & Entrepreneurial characteristics & 420 & 72.0474 & $<0.0001^{* * *}$ \\
\hline & Push and pull factors & 425 & 53.1658 & $<0.0001^{* * *}$ \\
\hline & The window of opportunity & 422 & 85.1545 & $<0.0001^{* * *}$ \\
\hline \multirow{10}{*}{ 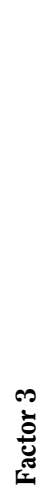 } & Elements included in a business plan & 418 & 109.4247 & $<0.0001^{* * *}$ \\
\hline & Calculation of break-even analysis & 423 & 171.3251 & $<0.0001^{* * *}$ \\
\hline & Resource requirements & 429 & 86.6104 & $<0.0001^{* * *}$ \\
\hline & Starting a business & 426 & 59.3508 & $<0.0001^{* * *}$ \\
\hline & Various business forms & 424 & 83.1985 & $<0.0001^{* * *}$ \\
\hline & Networking and support organisations & 426 & 72.3250 & $<0.0001^{* * *}$ \\
\hline & Systems in a family business & 426 & 67.3940 & $<0.0001^{* * *}$ \\
\hline & Understanding franchising & 423 & 56.6551 & $<0.0001^{* * *}$ \\
\hline & Growth strategies & 423 & 116.5241 & $<0.0001^{* * *}$ \\
\hline & Methods to determine the value of an existing business & 424 & 108.4472 & $<0.0001^{* * *}$ \\
\hline
\end{tabular}

$\mathrm{P} * * *$ Statistically significant differences

$\alpha<0.05$ (95 per cent confidence level)

$\alpha<0.001$ (99 per cent confidence level)

From Table 3 it is evident that the students perceived that they gained entrepreneurial skills in all the areas measured within the course content. Although it is an expected finding, it still empirically provides evidence that, by using a practical technique, the project succeeded in teaching entrepreneurial skills to a large group of first-year students. Furthermore this finding will be very valuable to other universities who also teach this course content and use the textbook: Entrepreneurship: A South African perspective.

The total sample was split into two groups: the group that enjoyed taking part in the project (referred to as the Yes group) and the group that did not enjoy taking part in the project (the No group). Table 4 presents the Independent t-test which was carried out on these two groups to measure their skills before the project. Furthermore the test was carried out on the three course content factors identified in the factor analysis. 
Table 4: Independent t-test: comparison of the Yes and No groups on the three course content factors before the project

\begin{tabular}{|l|l|l|l|l|l|}
\hline \multirow{2}{*}{ Factor } & \multicolumn{2}{|l|}{ Mean } & \multicolumn{2}{l|}{ Std deviation } & \multirow{2}{*}{ Mann-Whitney*** } \\
\cline { 2 - 6 } & Yes group & No group & Yes group & No group & \\
\hline $\begin{array}{l}\text { Creativity and } \\
\text { innovation }\end{array}$ & 2.2830 & 2.3536 & 0.4559 & 0.5823 & 0.0701 \\
\hline $\begin{array}{l}\text { Entrepreneurial } \\
\text { characteristics and } \\
\text { orientation }\end{array}$ & 2.3471 & 2.3284 & 0.5387 & 0.5267 & 0.6847 \\
\hline $\begin{array}{l}\text { Routes to } \\
\text { entrepreneurship }\end{array}$ & 2.1199 & 2.1170 & 0.4520 & 0.4733 & 0.9521 \\
\hline
\end{tabular}

$* * *$ Statistically significant differences

$\alpha<0.05$ (95 per cent confidence level)

$\alpha<0.001$ (99 per cent confidence level)

Table 4 confirms that there were no statistically significant differences between the skills level before the project took place in the group who enjoyed the project and the group who did not enjoy the project. It is interesting to note that the means of all three factors for both groups are very similar. This indicates that the groups were not different before the measurement. This is significant since any changes that occur in the groups as a result of the project they participated in are fundamental. Table 5 presents the independent t-test which was carried out on these two groups to measure their skills after the project. Table 5 further highlights whether the two groups still remained similar in terms of their skills after the groups participated in the project.

Table 5: Independent t-test: comparison of the Yes and No groups on the three course content factors after the project

\begin{tabular}{|l|l|l|l|l|l|}
\hline \multirow{2}{*}{ Factor } & \multicolumn{2}{|l|}{ Mean } & \multicolumn{2}{l|}{ Std deviation } & \multirow{2}{*}{ Mann-Whitney*** } \\
\cline { 2 - 5 } & Yes group & No group & Yes group & No group & \\
\hline $\begin{array}{l}\text { Creativity and } \\
\text { innovation }\end{array}$ & 2.7915 & 2.5731 & 0.3422 & 0.4862 & $<0.0001^{* * * *}$ \\
\hline $\begin{array}{l}\text { Entrepreneurial } \\
\text { characteristics and } \\
\text { orientation }\end{array}$ & 2.8413 & 2.7593 & 0.2311 & 0.2769 & $0.0043^{* * *}$ \\
\hline $\begin{array}{l}\text { Routes to } \\
\text { entrepreneurship }\end{array}$ & 2.6742 & 2.5983 & 0.3042 & 0.3419 & $0.0341^{* * *}$ \\
\hline
\end{tabular}

$* * *$ Statistically significant differences

$\alpha<0.05$ (95 per cent confidence level)

$\alpha<0.001$ (99 per cent confidence level)

All the factors show a statistically significant difference between the two groups after the project. Table 5 verifies that the group who enjoyed the project improved more in terms of their skills after the project took place. This group gained more skills from the project than did the group who did not enjoy the project. It statistically proves that positive emotions, feelings and attitudes can contribute to the success of a project. 


\section{Discussion of findings}

When revisiting the hypotheses and propositions, it is imperative to highlight the relevant findings that prove the acceptance or rejection of the hypotheses and propositions. Two hypotheses were tested and two propositions were stated. Based on the empirical findings, summarised in Table 3 , the respondents gained and improved in all the entrepreneurial skills after the project, indicating that the project assisted them in learning those skills. Therefore, the null hypothesis is rejected and the alternative hypothesis accepted. The alternative hypothesis $\left(\mathrm{H}_{\mathrm{a}}\right)$ states that a large group of entrepreneurship undergraduate students had the perception that they gained entrepreneurial skills due to the project-based learning approach.

The total sample was divided into two groups, one being the group who indicated that they enjoyed participating in the project ( 70 per cent), the other being the group who indicated that they did not enjoy participating in the project (30 per cent). Table 4 illustrates that there was no statistically significant difference between the skills level of the two groups before they participated in the project. Table 5, on the other hand, provides a clear statistically significant difference between the skills level of the two groups after the project. The group who enjoyed participating in the project gained and improved their entrepreneurial skills levels more than the group who did not enjoy the project. Therefore, the second null hypothesis is rejected and the alternative hypothesis accepted. The alternative hypothesis $\left(\mathrm{H} 2{ }_{\mathrm{a}}\right)$ stated that the students who enjoyed the project learnt more than the students who did not enjoy the project.

The first proposition - that the students' overall impression of the project is negative - can be rejected, based on the outcome of the descriptive statistics. The majority of the respondents ( 90 per cent) indicated that their overall impression of the project was average or positive. Only 10 per cent indicated that they had a negative overall impression. The second proposition stated that the students did not gain skills over and above the course content skills from participating in the project. Based on the following skills that were gained, the proposition can be rejected:

- $\quad$ presentation and communication skills

- entrepreneurial application - how to start one's own business

- teamwork

- $\quad$ knowledge of entrepreneurial skills

- creativity and innovation

- $\quad$ preparation for tests and the examination

\section{Conclusion}

The literature review maintained that South African tertiary institutions should focus on unconventional methods of teaching entrepreneurship. Outside classroom activities are introduced as a practical method of teaching entrepreneurship. Entrepreneurship is seen as a course that cannot be taught without a practical component, for example exposing students to real-life situations and entrepreneurs. The challenge, however, is to use these methods to teach entrepreneurship to more than 1500 first-year undergraduate students. This paper introduced a teaching method aimed at using an outside classroom practical project together with ways of assessing it. The OBS 124 entrepreneurship exhibition project provided the first-year students with the opportunity to portray entrepreneurship in their own creative way.

A research questionnaire was given to a sample of 460 students to measure the effect of the project on their entrepreneurial skills level. Factor analysis was executed to confirm the validity and reliability of the measuring instrument. Three factors were generated, namely, Creativity and innovation (Factor 1); 
Entrepreneurial characteristics and orientation (Factor 2) and Routes to entrepreneurship (Factor 3). These three factors were labelled as the three course content factors that were used to measure whether entrepreneurial skills were gained. Based on the empirical findings, this paper demonstrates that this project-based learning approach is an effective method of teaching entrepreneurship to a large group of undergraduate students. Furthermore, it highlights the fact that certain entrepreneurial skills can be taught and that this can be done by using more creative pedagogies than the traditional classroom lecture. In addition, the paper illustrated how entrepreneurial skills can be gained by a large group of students if a practical approach is used.

To conclude, the assessment of the OBS 124 project, and the fact that a large number of students participated in it, contributed to the development of a novel practice within the University of Pretoria. Other institutions are encouraged to learn from this experience and adopt the notion that entrepreneurship can be taught to any number of students by using unconventional methods of teaching.

\section{Note}

1 Students and educators use the internet-based click-up system to communicate inside and outside the classroom in ways that make sense to their learning. This tool is a commercially available Blackboard Learning Management System (LMS).

\section{References}

Antoncic, B., C. Scarlat and B. Erzetic 2004. "The quality of entrepreneurship education and the intention to continue education: Slovenia and Romania. Managing Global Transitions 3(2):197-212.

Bechard, J. P. and D. Gregoire. 2005. Understanding teaching models in entrepreneurship for higher education. In The dynamics of learning entrepreneurship in a cross-cultural university context, ed. P. Kyro and C. Carrier, 104-134. Tampere: Faculty of education, University of Tampere.

Bell, J. R. 2008. Utilization of problem-based learning in an entrepreneurship business planning course. New England Journal of Entrepreneurship 11 (1):53-61.

Blumenfeld, P. C., E. Soloway, R. W. Marx, J. S. Krajcik, M. Guzdial and A. Palincsar. 1991. Motivating project-based learning: Sustaining the doing, supporting the learning. Educational Psychologist 26(3) and (4):369-98.

Botha, M. 2006. Measuring the effectiveness of the women entrepreneurship programme training intervention on potential, start-up and established women entrepreneurs in South Africa. Unpublished DCom thesis, University of Pretoria.

Co, M. J. and B. Mitchell. 2006. Entrepreneurship education in South Africa: A nationwide survey. Education and Training 48 (5):348-59.

Cooper, D. R. and P. S. Schindler. 2001. Business research methods. 7th ed. New York: McGraw Hill.

Dhliwayo, S. 2008. Experiential learning in entrepreneurship education: A prospective model for South African tertiary institutions. Education and Training 50 (4): 329-40.

Drucker, P. F. 1985. Innovation and entrepreneurship. New York: Harper \& Row.

Fayolle, A. and B. Gailly. 2008. From craft to science: Teaching models and learning processes in entrepreneurship education. Journal of European Industrial Training32 (7):569-93.

Fayolle, A., B. Gailly and N. Lassas-Clerc. 2006. Assessing the impact of entrepreneurship education programmes: A new methodology. Journal of European Industrial Training 30 (9):709-20.

Fiet, J. O. 2000. The pedagogical side of entrepreneurship theory. Journal of Business Venturing 16 (2):101-117.

Frank, M., I. Lavy and D. Elata. 2003. Implementing the project-based learning approach in an academic engineering course. International Journal of Technology and Design Education 13:273-88. 
Gartner, W. B. and K. H. Vesper. 1994. Experiments in entrepreneurship education: Success and failures. Journal of Business Venturing 9:179-87.

Gibb, A.A. 1997. Small firms' training and competitiveness: Building on the small business as a learning organisation. International Small Business Journal 15(3):13-29.

Hannon, P.D. 2006. Teaching pigeons to dance: sense and meaning in entrepreneurship education. Education and Training 48 (5):296-305.

Heinonen, J. 2007. An entrepreneurial-directed approach to teaching corporate entrepreneurship at university level. Education and Training 49 (4):310-324.

Heinonen, J. and S. Poikkijoki. 2006. An entrepreneurial-directed approach to entrepreneurship education: mission impossible? Journal of Management Development 25 (1):80-94.

Henry, C., F. Hill and C. Leitch. 2005. Entrepreneurship education and training: Can entrepreneurship be taught? Part I. Education and Training 47 (2): 98-111.

Hills, G. E. 1988. Variations in university entrepreneurship education: An empirical study of an evolving field. Journal of Business Venturing 3:109-22.

Hynes, B. 1996. Entrepreneurship education and training - introducing entrepreneurship into nonbusiness disciplines. Journal of European Industrial Training. 20 (8):10-17.

Jamieson, I. 1984. Schools and enterprise. Education for Enterprise. 1 (1):7-18.

Katz, J. A. 2003. The chronology and intellectual trajectory of American entrepreneurship education. Journal of Business Venturing 18(2):283-300.

Klandt, H. 1993. Methods of teaching: What is useful for entrepreneurship education? In: Proceedings of the conference on Internationalising Entrepreneurship Education and Training (IntEnt93), Vienna, 5-7 July: 34-43.

Kuratko, D. F. 2005. The emergence of entrepreneurship education: development, trends, and challenges. Entrepreneurship: Theory and Practice 29 (5):577-97.

Kuratko, D. F. and Hodgetts, R. M. 2004. Entrepreneurship: Theory, process, practice. Mason, OH: South-Western College Publishers.

Laukkannen, M. 2000. Exploring alternative approaches in high-level entrepreneurship education: Creating micro mechanisms for endogenous regional growth. Journal of Entrepreneurship and Regional Development 12 (1):25-47.

Law, K. M. Y. and Chuah, K. B. 2004. Project-based action learning as learning approach in learning organisation: the theory and framework. Team Performance Management 10 (7/8):178-86.

Leedy, P. D. 2004. Practical research. 6th ed. London: Macmillan.

McMullan, W. E. and W. A. Long. 1987. Entrepreneurship education in the nineties. Journal of Business Venturing 2 (3):261-75.

Matlay, H. 2006. Researching entrepreneurship and education. Part 2: What is entrepreneurship education and does it matter? Education and Training 48 (8/9):704-18.

Morris, M. H., D. F. Kuratko and M. Schindehutte. 2001. Towards integration: understanding entrepreneurship through frameworks. Entrepreneurship and Innovation, February: 35-49.

Nieman, G. H., J. Hough and C. Nieuwenhuizen, eds. 2003. Entrepreneurship: A South African perspective. Pretoria: Van Schaik.

Okudan, G. E. and S. E. Rzasa. 2006. A project-based approach to entrepreneurial leadership education. Technovation 26 (2):195-210.

O'Neill, R. C. 2004. Entrepreneurship as a subject at university. The South African experience. http:// www.sbaer.uca.edu/research/icsb/1995/pdf/15/pdf (accessed 12 November, 2008).

Pretorius, M., J. J. van Vuuren and G. H. Nieman. 2005. Critical evaluation of two models for entrepreneurial education: An improved model through integration. The International Journal of Educational Management 19 (5):413-27.

Rae, D. 1999. The Entrepreneurial Spirit. Dublin: Blackhall Publishing. 
Scarbrough, H., M. Bresnen, L. F. Edelman, S. Laurent, S. Newell and J. Swan. 2004. The processes of project-based learning: an exploratory study. Management Learning 35 (4):491-506.

Solomon, G. 2007. An examination of entrepreneurship education in the United States. Journal of Small Business and Enterprise Development 14 (2):168-82.

Thompson, K. J. and J. Beak. 2007. The leadership book: Enhancing the theory-practice connection through project-based learning. Journal of Management Education 31 (2):278-91.

Timmons, J. A. 2003. Entrepreneurial thinking: Can entrepreneurship be taught? Coleman Foundation White Paper Series.

Timmons, J. A. and S. Spinelli. 2005. New venture creation: Entrepreneurship for the 21st century. 6th ed. New York: McGraw-Hill/Irwin.

\section{Author}

Melodi Botha is currently employed by the University of Pretoria as a senior lecturer in Entrepreneurship at the Department of Business Management. Her fields of expertise include business plan compilation, opportunity recognition and empowering women entrepreneurs in South Africa.

Dr Melodi Botha

Department of Business Management

Economic and Management Sciences Building

University of Pretoria

Pretoria

South Africa

E-mail: melodi.botha@up.ac.za 